University of Wollongong

Research Online

$1-1-2016$

\title{
The big end of town meets the local council: the investment habitus of four sets of Australian councils during the GFC
}

\author{
Gregory Jones \\ University of Southern Queensland, gjones@uow.edu.au \\ Claire Beattie \\ University of Southern Queensland \\ Graham D. Bowrey \\ University of Wollongong, gbowrey@uow.edu.au \\ Ciorstan Smark \\ University of Wollongong, csmark@uow.edu.au
}

Follow this and additional works at: https://ro.uow.edu.au/buspapers

Part of the Business Commons

\footnotetext{
Research Online is the open access institutional repository for the University of Wollongong. For further information contact the UOW Library: research-pubs@uow.edu.au
} 


\title{
The big end of town meets the local council: the investment habitus of four sets of Australian councils during the GFC
}

\author{
Abstract \\ The Global Financial Crisis of 2008 led to a substantial write-down in the value of investments such as \\ collateralised debt obligations (CDOs) with one class of investors being NSW Local councils. This article \\ analyses interviews with four different investor types (or sets) of local councils, each of which took a \\ substantially different approach to CDO investment. This categorisation into sets was based on \\ interviews of 28 individuals working within 14 local councils as well as commentaries on legal cases \\ involving a class action of local councils suing Lehman Brothers Australia as well as Grange Securities \\ over losses in their investments. This article adopts Bourdieu's Theory of Practice to describe and explain \\ behaviour regarding decisions to invest (or not) in CDOs. Interesting themes arise regarding differing \\ views on the appropriate role of local councils, and on the degree and form of 'capital' (which includes \\ knowledge, competencies, skills, and economic resources) that a council should have before investing in \\ sophisticated financial products. This article explores the role that field, habitus, and capital played in \\ moderating and influencing council investment making decisions. The analysis shows that these \\ Bourdieuian concepts can be utilised to help explain individual behaviour. This case study shows that \\ excessive capital left in the hands of individuals may result in suboptimal decision making. Local councils \\ may need to consider ways of implementing policies and procedures that can be used to moderate \\ individual action.

\section{Disciplines \\ Business}

\section{Publication Details} \\ Jones, G., Beattie, C., Bowrey, G. \& Smark, C. (2016). The big end of town meets the local council: the \\ investment habitus of four sets of Australian councils during the GFC. Australian Journal of Public \\ Administration, 75 (4), 441-456.
}




\section{The Big End of Town Meets the Local Council: The Investment}

\section{Habitus of Four Sets of Australian Councils During the GFC}

Dr Greg Jones,

University of Southern Queensland Gregory.Jones@USQ.edu.au

Dr Claire Beattie,

University of Southern Queensland Claire.Beattie@usq.edu.au

Dr Graham Bowrey,

University of Wollongong GBowrey@uow.edu.au

Dr Ciorstan Smark,

University of Wollongong CSmark@uow.edu.au

Contribution of each author is $25 \%$.

The Global Financial Crisis of 2008 led to a substantial write-down in the value of investments such as Collateralised Debt Obligations (CDOs) with one class of investors being NSW Local councils. This paper analyses interviews with four different investor types (or sets) of local councils, each of which took a substantially different approach to CDO investment. This categorisation into sets was based on interviews of 28 individuals working within 14 local councils as well as commentaries on legal cases involving a class action of local councils suing Lehman Brothers Australia as well as Grange Securities over losses in their investments. This article adopts Bourdieu's Theory of Practice to describe and explain behaviour regarding decisions to invest (or not) in CDOs. Interesting themes arise regarding differing views on the appropriate role of local councils, and on the degree and form of "capital" (which includes knowledge, competencies, skills and economic resources) that a council should have before investing in sophisticated financial products. This paper explores the role that field, habitus and capital played in moderating and influencing council investment making decisions. The analysis shows that these Bourdieuian concepts can be utilised to help explain individual; behaviour. This case study shows that excessive capital left in the hands of individuals may result in suboptimal decision making. Local councils may need to consider ways of implementing policies and procedures which can be used to moderate individual action.

Keywords: Local Government Investment, Investment policy, Decision making, Bourdieu, habitus. 


\section{Introduction}

The Global Financial Crisis (GFC) of 2008 led to a substantial write down in the value of some investments such as Collateralised Debt Obligations (CDOs) by the product issuers. One group of investors holding some of these CDO assets were NSW local councils who were permitted (under the Local Government Act, 1993) to invest council funds in a range of sophisticated investment products, such as CDOs. Investment in these products was conditional that these products held a sufficiently high credit rating as determined by ratings agencies such as Moody's Investors Services Inc., Standard and Poor's Investors Service Inc. or Fitch Ratings. As a result of the collapse of the underlying value of the assets backing these financial derivative products, NSW local councils have written down their financial investments to the tune of hundreds of millions of dollars (Barton 2005; Cole 2008). "At the end of 2006-07 financial year, local councils in NSW had invested $\$ 590$ million dollars in structured financial products such as collateralised debt obligations (CDOs). Six months later, the market value of these investments dropped \$200 million to \$390 million" (Jones \& Bowrey 2010, p38). Following the onset of the GFC, in July 2008, the Director General of the NSW Department of Local Government, Garry Payne, issued revised ministerial investment orders (NSW DLG 2008) emphasising the need for councils to exercise due care and diligence in their financial operations and significantly curtailing the investments in which local councils should entrust council funds. The NSW State Government commissioned a seminal report (Cole 2008) outlining the questionable investment practices of local councils and the possible ramifications of post-GFC write downs. By January 2011, the Local Government Act 1993 - Investment Order (Local Government Act 1993-Investment Order 2011) (relating to investments by councils) offered councils very limited, prescriptive and conservative investment options with an enhanced emphasis on fiduciary responsibility and prudence.

While the Australian Securities and Investment Commission (ASIC) were aware as early as 2007 that NSW local councils were investing in CDOs, and, even earlier during 2005, the Reserve Bank Australia (RBA) had identified that potentially CDOs were a high risk product (Black \& Rai 2005), there was little done to prevent investment in them. Ultimately the decision to invest (or not) in CDOs, was in the hands of individual councils. Local councils were able to adopt a more conservative approach if they wished and could have chosen to invest only in low risk, capital secured products.

This paper explores the perceptions of finance managers from four groups (or sets) of local councils, with each group taking a substantially different approach to investing in CDOs (and other sophisticated investment products). The study uses the lens of Bourdieu's Theory of Practice to describe and explain the behaviour of four groups of councils regarding their decisions to invest (or 
not) in CDOs. Two interesting themes emerge in this study. Firstly, the local councils' differing views on the appropriate role of local councils; in Bourdieu's terms, this could be seen as "habitus". Secondly, the degree and form of "capital" that a council should have before proceeding with an investment in sophisticated financial products; in Bourdieu's terms this includes knowledge, competencies, and skills as well as capital in the usual meaning of economic resources. The contribution of this article is to explore how four groups of local councils came to quite divergent interpretations of what constitutes an appropriate investment and, given this divergence of interpretation, offer some policy suggestions for local council corporate governance in the future.

\section{Background to NSW Local Councils Investments}

NSW local councils' financial investments are controlled by the legislative conditions imposed by the NSW state government. Introduction of the 1993 Local Government Act saw the beginning of significant changes to the types of investments that councils were permitted to consider. The 1993 Local Government Act made reference to the NSW 1925 Trustees Act and imposed the condition that councils should consider themselves trustees of public funds with a responsibility to exercise due care and diligence in the investment of public monies (NSW Trustees Act 1925, Section 14). However, later amendments to the 1993 Local Government Act removed the reference to the Trustees Act 1925 (Dollery, Fletcher \& Rao 1998; Dollery, Wallis \& Allan 2006) thereby weakening the stewardship component of managing public monies. These reforms to the financial reporting requirements of local governments were promoted on the basis that they would result in an improvement in the usefulness of the reports for decision making and enhance accountability (Carnegie 2005).

The Department of Local Government (DLG) provides guidance to councils (DLG 2006) in interpreting the provisions within the Act. Dredge (2001) proposed that the 1993 NSW Local Government Act reflects the changes which have occurred in society and the expectations which are placed on government bodies. This Act was designed to include provisions to accommodate the changes society had undergone by emphasising "greater accountability by local councils to their communities; more professional management of the day-to-day activities of local councils; and increased flexibility to devise methods of efficient service delivery and the performance of regulatory activities" (Dredge 2001 p. 370). Prior to the collapse of the CDO market in 2007, and the subsequent write down of investments in those types of products, NSW local councils had been permitted to invest in a diverse range of products. Predominately they were allowed to invest in products that had either, been issued by a company with a credit rating of A or better, or were securities which had been given a credit rating of $A$ or better. Approved products have been 
stipulated by the NSW Treasury and have been subject to a series of changes over the last decade and a half. Significant changes were made to the guidelines after the GFC began and the release of the Cole Report (2008) which highlighted the losses (of over \$200 million) suffered by NSW Local councils.

\section{Collaterised Debt Obligations (CDOs)}

CDOs were created out of the desire of banks to sell their credit risk on to third party investors via the capital markets. CDOs are highly complex financial tools that repackage individual loans into a product that can be sold on the secondary market. They are special purpose vehicles that acquire a range of portfolios and issue securities which are primarily backed by the cash flows expected from the acquired assets. These assets were often then sold on to entities based in locations such as the Cayman Islands or Ireland as a means to ensure that there was remoteness from the issuer (Benmelech \& Dlugosz 2009, p. 4). "They are essentially a pool of debt instruments in which investors take tranches with different levels of risk" (Tett 2007). Or, as described by Ray (2006, p. 184), CDOs are investment shells which "contain all types of rated and unrated securities which include bonds, promissory notes, project-finance loans, leases, etc." which were then sold as a package. CDOs often contain hundreds of underlying assets and to model the cash flow from them requires the use of sophisticated cash flow software (Benmelech \& Dlugosz 2009). One of the notable aspects of CDOs in which councils were investing was that they were instruments that packaged the expected cash flows from mortgage debt rather than the mortgage debt itself (Rolfe 2009). This meant that owners of the CDOs were only entitled to the cash flow from the investments and had not right or hold on the assets associated with the cash flow. These products were substantially different from the traditional mortgage and asset back products.

As CDOs were typically offering 2-3\% greater return than similarly rated bonds it appeared logical for local councils to try to maximise the returns from their investments if they were unaware of the increased associated risk. However, recognition of the risk intrinsically incorporated into CDOs was difficult even for sophisticated investors. CDOs were very prevalent in the financial product market during the early 2000 s and were able to offer the prospect of diversification to potential investors (Partnoy \& Skeel 2006). For institutional investors, who were confined by restrictions on their portfolio, CDOs provided the opportunity to invest in traditionally non-marketable assets. When this was coupled with the prevailing economic conditions showing reasonably stable $2 \%$ growth in GDP (RBA 2012), steadily increasing interest rates and increasing bond returns from 2000-2001 (Eslake 2011a, 2011b), it created an expectation that capital growth and investment returns would continue into the foreseeable future. However, what occurred, primarily due to the nature of the assets 
backing the CDOs was the creation of a bubble which overinflated the true value of CDOs (Adam, Jhooty \& Wong 2004; Levin \& Coburn 2011; Tett 2007, 2009a, 2009b, 2010).

\section{Theoretical Model}

This paper adopts a Bourdieuian approach to exploring the underlying decision process that resulted in local councils investing in CDOs. As a social theorist, Bourdieu made a substantial contribution to the development of what is now described as practice theory. For Bourdieu, (1977) practice is based upon the inherent pre-existing dispositions of the actors. He proposed that the actors seek to improvise and pursue strategic goals and interests, while acting within their societal and situational environments which also have strong existing internal norms. Wacquant (2004) explained that Bourdieu sought to show that social agents develop strategies which are adapted to the area which they inhabit and that these strategies are unconscious results of prior learning and social expectations. Bourdieu aimed to analyse actors in the practical arena, while considering their performance, and their meaning as part of a social product which was linked to their cultural and symbolic actions (Breiger 2000). Bourdieu's concepts are highly interdependent and the way in which he uses them is intended to guide research and elicit research questions in a variety of social environments while exploring the existing interrelationships (Hurtado 2010, p. 54).

Bourdieu sought to connect empirical research with his theoretical ideas and offer insights into "how objective and subjective factors are interrelated" (Berard 2005, p. 205). His work was grounded in the way everyday life operated and focused on the culture or as he posited, a "theory of practice" (Bourdieu 1977; Webb, Schirato \& Danaher 2002). Bourdieu (1977) proposed that his "theory of practice" should not be considered as a pure theory, but as a framework which could provide the tools with which to develop understanding of practice. He was adamant about the inseparability of structure, subjectivity and the pre-reflectivity character of practice. Bourdieu (1987) contended that social order is produced through relations of domination, where the power to make groups and instil them with authority is a representation of symbolic power (Bourdieu 1987). In this view agents (or actors) develop ways of comprehending the world through developing dispositions or inclinations that support the patterns, purposes and principles of the social context in which they operate. The main terms he used to describe this theory of practice were habitus, field, and capital.

Bourdieu's framework only mentions the terms, field, capital and habitus, however integral to this approach is the understanding that they only have meaning when the actors participate within them. Bourdieu $(1977,1984,1990 b)$ later further divided capital into a range of categories such as social capital, cultural capital and symbolic capital. The following Figure 1 provides an overview of how Bourdieu's framework can be perceived. 


\section{Figure 1: Bourdieu's Framework}

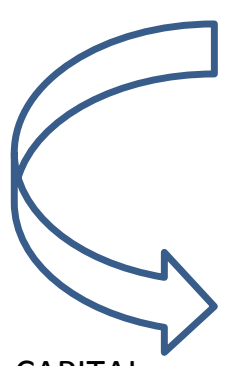

CAPITAL

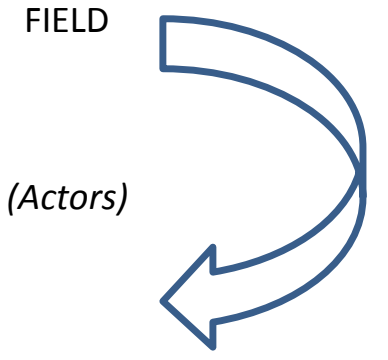

HABITUS

(Adapted from Bourdieu 1977, 1990)

Bourdieu perceives power as something that is created through culture and symbolism, which is then re-legitimised through interactions between the agent and the organisational structure. The primary way in which he viewed this occurring is through what he labelled 'habitus'. Habitus is essential to Bourdieu's theory (Berard 2005, p. 201) and is described as a socially constructed set of dispositions (Bourdieu 1977, 1996). It captures the 'cultural unconscious' that shapes action through encapsulating the dialect between structure and agency. Habitus is the residue of past actions, knowledge, know how, behaviour and responses that now function in the present and influence behaviour (Bourdieu 1984). Habitus is therefore the social norms or tendencies that guide behaviour, actions and thinking (Webb et al. 2002).

Cultural fields are made up of a range of "rules, rituals, conventions, categories, designations, appointments and titles which constitute an objective hierarchy" (Webb et al. 2002, p. 21), and lead to the production and authorisations of particular discourse and activities. Local councils are cultural fields with their own rules, policies and structures which are expected to lead to certain activities. Finance managers working in NSW local governments function in a variety of fields which are strongly interwoven. While some of these fields are highly regulated and prescriptive others are less rigid and are potentially adaptable to the power exerted by individuals or other fields. While there are a wide variety of fields which could influence the decision-making of local councils, for the purpose of this paper, we have restricted the fields to the three most influential. The primary fields were the individual councils, the field created by the Local Government ministerial investment policies and the financial professionals group. This group consisted of finance managers employed within metropolitan councils to manage the investments of the councils. 
In this research, we utilise Bourdieu's theory of practice to identify the factors that were instrumental in local council finance managers' decisions to invest funds in CDOs. We consider each of the Bourdieu's elements in the following analysis.

\section{Method}

Analysis of all 152 NSW council financial records demonstrated that there was a roughly even distribution between councils who chose to invest in CDOs and those who did not. Further analysis of council demographics (evaluating councils from remote, regional and metropolitan areas) highlighted that irrespective of the area where the councils operated and the resources they managed there was no significant difference in whether they decided to invest in CDOs or not. Metropolitan councils in NSW were chosen for this study as they had more available funds within their investment portfolios than their regional and remote counterparts. This meant that their decisions to invest, or not, in CDOs was not influenced by their availability of funds. Interviews were conducted with 28 individuals working within 14 local councils, an external auditor responsible for the audits of 20 local councils and an investment advisor who provided advice to 17 NSW local councils. The participants of this study worked within NSW local councils and were responsible for making financial investment decisions.

The actions and decision-making processes used within councils fell naturally into three distinct groups; those who chose not to invest in CDOs (the pseudonym used for this group of councils is Applewood Councils), those who chose to invest in CDOs with a poor knowledge of the products (pseudonym Blackwood Councils), and those who chose to invest in CDOs a good knowledge of the products (pseudonym Cedarwood Councils).. For the purpose of this article, we have represented three of these groups as "types" of councils and used pseudonyms to maintain confidentiality. The fourth group (four councils with significant losses who invested heavily in CDOs and subsequently sued Lehman Brothers and their marketing subsidiary, Grange Securities) we refer to by their actual names as they are included by accessing public documents and publically available commentaries. These councils exhibit many of the same characteristics of the councils in the "Blackwell" category, but have been put into a separate category because of the extent of their losses. They all declined to be interviewed (with one commenting that the mere mention of CDOs made them nauseous), therefore no primary data is available. The actions described are representative of councils within these groups and have been presented as though they are four groups of councils to demonstrate the behaviours and processes they followed. The following Table 1 identifies the names given to each group, the number of councils and participants within each. 
Table 1: Participants in Interviews: (The council names and the participant names have been changed to pseudonyms for preservation of anonymity)

\begin{tabular}{|l|l|l|}
\hline Council group & Council profile (NSW Metropolitan council) & Interviewees \\
\hline $\begin{array}{l}\text { Applewood } \\
\text { Councils }\end{array}$ & $\begin{array}{l}\text { Applewood councils did not invest in CDOs. There were 4 } \\
\text { councils in this group. }\end{array}$ & $\begin{array}{l}7 \text { interview } \\
\text { participants }\end{array}$ \\
\hline Blackwell & $\begin{array}{l}\text { This group was comprised of } 6 \text { different councils. This group } \\
\text { of councils had CDO investment portfolios ranging from \$10 to } \\
\$ 50 \text { million. }\end{array}$ & $\begin{array}{l}11 \text { interview } \\
\text { participants }\end{array}$ \\
\hline Cedarvale & $\begin{array}{l}\text { This group was comprised of } 4 \text { different councils. These } \\
\text { councils had internal policies which allowed them to invest in } \\
\text { CDOs but they also had strong internal governance and } \\
\text { financial oversite to assess the risks associated with financial } \\
\text { products. }\end{array}$ & $\begin{array}{l}8 \text { intervipants } \\
\text { particis }\end{array}$ \\
\hline
\end{tabular}

\section{Fields}

From the perspective of the finance managers, State Government through ministerial investment policy guidelines provided an example of highly regulated fields. These policy guidelines imposed restrictions detailing the types of financial investment products in which local councils were able to invest. The investment policies dictated to NSW local councils through the ministerial investment guidelines have changed over time. When the 1993 Local Government Act was introduced, it referenced the NSW 1925 Trustees Act and required that councils acknowledge that they were custodians and trustees of public assets and incorporated protection of investment capital as a priority. Thereby stipulating that councils had a fiduciary duty to preserve capital for the benefit of future generations. Since 1993 there has been a general widening of the types of products in which councils were able to invest. Later amendments to the 1993 Local Government Act removed the reference to the Trustees Act 1925 (Dollery, Fletcher et al. 1998; Dollery, Wallis et al. 2006). By 2000 the guidelines incorporated investment in rated products such as CDOs (NSW DLG 2000), thereby providing an opening for more aggressive and risk-accepting investments by local councils. Similarly finance managers are also governed by the investment policies and practices of their individual local councils (which also have to comply with the State investment guidelines), thereby creating firm boundaries within which they have to function. However these policies are influenced by the particular field and habitus of the organisation and capital (discussed below) of those responsible for investment decisions. 
An example of where the field within which finance managers' practice is less restrictive and where influence may be exerted is the finance managers' groups. These groups were made up of finance managers from up to 20 different councils and provided finance professional an opportunity to meet and discuss issues faced by their members. The purpose of these meetings was to provide an opportunity for finance managers from different councils to get together and exchange information knowledge and experiences with the goal of improving practices within the profession. This field has the potential to exert influence on the perceptions and actions of the finance managers and then, through the actions of finance managers in other fields, to be extended beyond that original field. Bourdieu recognised that if the conditions in a field changed significantly, then the habitus would still generate the conditions previously expected and would no longer meet the objectives of the field (Hurtado 2010). He suggested that this would cause the individuals within a field to be more reflective, and consider their practices, which may then lead to modifications of those practices. Therefore influences in a field have the capacity to shape the existing habitus and the practices of those functioning within the field.

This field appeared to influence the Applewood Council groups' decisions to not invest in CDOs. When a finance manager attended external meetings which operated partly as a platform for marketing these instruments. Despite the perceived credibility due to advertising at a professional event Applewood group were sceptical of the claims made and resisted the peer pressure associated with the external groups.

\begin{abstract}
Applewood Council \#1
It was quite bizarre when it was all happening because there is a financial professionals group and we have a conference. We meet once a month as in a ... group and there were these "spruikers" who were actually sponsoring the [group]. The local government managers association were going to the conferences and talking about all these investments. [The spruikers were] trying to use it as a platform to get on board as well. I think that some councils fell for all that said "oh it must be alright they are sponsoring the financial professionals". [They were] throwing money at the local government managers association so it was spruiking in a big way if you ask me'... just admitted that I did not understand it. It just seemed too complicated and, obviously, if there is a bigger return, then there is always a bigger risk. That is the way we looked at it.
\end{abstract}

Thus, although the finance manager at this Applewood council was influenced by the group context he resisted the urge to conform and recognised that there was a contradiction between the rhetoric and the reality of the financial instrument. This reflects an interaction between the field and the habitus of the finance managers. 
The suggestion of a participant from council 1 that "some councils fell for all that" is evidenced by the fourth set of councils included in this study. For reasons unknown to the authors (although we speculate that several of the fourth type of councils were engaged in suing the marketers and or providers of the CDOs at the time that the interviews for this study were conducted), members of the set of councils who invested heavily in CDOs and lost a substantial amount of their investment did not want to be interviewed. Because of this, we have referred to the case notes and comments of judges in those cases that have now been concluded involving this set of councils. In order to characterise the Field of this fourth set of councils, we refer to the Federal Court's findings in Wingecarribee Shire Council v Lehman Brothers Australia Ltd where four councils brought a class action against Lehman Brothers.

The products Lehman's was selling were synthetic collateralised debt obligations (CDOs) that were so complex they were beyond comprehension for most people. The Court found these CDOs were only suitable for 'sophisticated investors', in the ordinary meaning of the words. The Councils were held to be unsophisticated investors even though they could technically be qualified as "sophisticated" under statute .... . An investor may be considered unsophisticated if they do not have the capacity to understand the product and its risks even if the investor would be classified as "sophisticated" under statute.

William Roberts Lawyers (2015) commenting on Wingecarribee Shire Council v Lehman Brothers Australia Ltd

This suggests that this group of councils had been influenced by the potential high returns without proper regard for the increased risk. These councils handed over the management of their portfolios and the financial investment decisions to an organisation that they perceived as being experts in that field. The fact that the organisation had a vested interest in selling and promoting CDOs was largely ignored. It is likely that these councils believed that they had discharged their accountability requirements by placing their investments in the hands of so called experts. In the Bourdieuian analysis it is likely that the habitus within each council (field) played a dominant role in investment decision making.

\section{Habitus}

In Bourdieu's terms habitus encompasses the social norms and values that inhabit organisational structures and guide individual behaviour. Activities that are divergent from these "unseens" can be problematic. In this study the aggressive sales tactics by CDO salesmen concerned the finance officers at each council. In terms of local government habitus, these aggressive marketing

\footnotetext{
${ }^{1}$ the legal categorisation of a sophisticated investor is any person or entity who has more the $\$ 500,000$ to invest. With the primary assumption being those with more than that amount to invest has the financial resources to be able to afford expert advice
} 
techniques violated the finance managers' sense of proper organisational structure. The sales strategy of disregarding the council hierarchy in order to sell the product caused finance managers to question the integrity and credibility of the salesman.

Applewood Council \#2:

We didn't like his [the CDO Salesman's] tactics either...Go to me, get knocked back, go to my boss, get knocked back, go to the general manager, get knocked back...The guy promoting them .. he was .. probably more of a salesman than an investment...advisor.

Cedarvale Council \#1:

They (CDO salesmen) were pushing right up to the director level. We know that they tried to push [this products to Councils'] ]CEOs and mayors in some councils. The Director [of the CDO marketing firm] who was there... certainly did approach him [the council CEO].

The participants also questioned the need to market the product so aggressively. This actually reduced the finance managers' confidence in the financial instrument because the claims seemed extraordinary. The rhetoric clashed with the intuition and conventional knowledge of the participants which meant they were less likely to adopt the product. In this sense, the legitimacy of the product was reduced because the context in which it had been introduced conflicted with the finance managers' habitus.

Blacwell Council \#1

They marketed it [the CDOs] as though you were doing something wrong if you didn't go into it [purchasing CDOs for your council]. They marketed it from the point of view that you [would have] great returns. I said "you are kidding me, are you telling me that I can put my grandmother's inheritance into a CDO and it will be safer than putting it into a high grade bank term deposit?" And she said "yes". So they had a hard sell where they tried to make people believe that you were doing the wrong thing if you weren't getting the best returns.

Blackwell Council \#1 interviewees also mentioned that they were concerned for younger local council finance managers being more vulnerable to aggressive sales techniques than more experienced and seasoned finance managers ("old heads" as they called them).

But I just wonder... there was some young blokes in there and some of those councils [with younger finance managers] invested more in CDOs.

Blackwell Council \#2 was also willing to defend their decision to invest in CDOs:

It is hard to say that the decision to invest in CDOs at this council was wrong. Just because they are CDOs does not mean that they are bad. The early CDOs ... the risk was not high, they were well secured.

While the participants from Blakwell Council \#2 described the early investments in CDOs as 'well secured', this was not entirely the case. The CDOs in which they had been investing were only 
backed by the cashflow from the assets. The owners of the CDOs had no right to the underlying asset from which the cash flow was generated.

Blackwell Council \#3 was also concerned with not wanting to look conservative:

[We] invested for the higher returns ... the returns were 50 to 100 base points above the term deposits

Additionally stating that:

[We]invested in CDOs mainly to show we were actively investing and not being conservative for conservativeness sake, it was [a]recognition that our portfolio wasn't getting [the] returns that private organisations were.

There was a clear desire by these Blackwell councils to show that they were willing and able to invest money for the councils and to get above normal returns, viewing this as what they were employed to do. Habitus in local councils can be vested in the organisation itself, or within the individuals working in the organisation. From the perspective of the local councils, prior experiences, both good and bad, develop a habitus which is capable of influencing future behaviour. Lack of experience with investment failure in the past also had the capacity to create a habitus where even the idea that financial investment may contain risk is not considered. Thus experience would shape the individual's habitus and make the more experienced manager less vulnerable to aggressive sales techniques.

Another example of how the habitus of the particular council managed (influenced) the behaviour of the investment manager was Applewood Council \#4, which had strict internal policies related to investments. This policy only allowed investments in products that were government secured (such as bank term deposits).

Applewood Council \#4: our investments are very vanilla ... we just invest in term deposits ... my job is to turn over the investments and get the best return I can within the constraints.

It was evident that those charged with investment decisions at Applewood Council \#4 felt frustration with not being able to pursue more aggressive investment products and felt they were being controlled by the internal council investment policy. This showed the ability of the habitus of the council to manage and control what they considered to be undesirable behaviour. However unpopular this may have been with the investment officers, ultimately this policy proved to be beneficial and effectively protected the council from undue losses.

Returning to the Federal Court's judgement in The Lehman Case, high pressure and misleading sales tactics were referred to by the Court on the part of both Lehman Brothers and their marketers, and 
the Court found that, in an attempt to attract investors, Lehman Brothers had misrepresented very complex and high-risk financial products to councils and charities around Australia as "safer than the four major Australian banks" when they were not (William Roberts Lawyers 2015). Additionally, "How was it that relatively unsophisticated council officers came to invest many millions of ratepayers' funds in these specialised financial instruments? That is the fundamental question at the heart of these proceedings," mused Justice Steven Rares, before pronouncing judgement in a case that has far-reaching implications for the regulation of financial services both here and internationally (Wingecarribee Shire Council v Lehman Brothers Australia (in liq) [2012] FCA 1028 at 14)... The Rares judgement provides the first definitive answer. It finds that Grange Securities, a wholly owned subsidiary of Lehman Brothers, breached its fiduciary duty and engaged in misleading and deceptive conduct in placing highly complex collateralised debt obligations in the portfolios of councils (O'Brien 2012). One of the reasons that this action was successful was that these councils handed over the management of their investment portfolios to Grange Securities, so it was not the councils who made the decision to invest in $\mathrm{CDO}$ s, it was Grange in their capacity as investment managers.

From a Bourdieuian perspective, habitus within these councils led them to decide to place the responsibility of managing financial investments in the hands of another entity. In these cases that entity was Grange Securities. These councils acted in the belief that they did not have the necessary skills in house to be able to make good and well informed investment decisions, and that by using an investment management entity their investment portfolio would be well managed. While their ability to recognise that they may not have had the skills to properly manage these investments, there also seems to have been a desire to divest themselves of their fiduciary responsibilities as they handed control to an outside entity. The habitus of these councils appears to encouraged the delegation of responsibility rather than maintain control themselves.

\section{Capital}

Bourdieu describes the concepts of field and capital as being the structural context in which action occurs. Struggles over various resources that actors decide are worth expending effort on define the stakes that are valued by the actors. Action is shaped by the recognition of those stakes and also by the resources (capital) available to the agents and also by the resources which are sought. While the traditional concept of capital (Emirbayer \& Johnston 2008) has typically related to money or financial resources (economic capital), the more modern approach has been to include other types of capital such as human and social capital. Hence, capital can refer to both the tangible and intangible resources which enable individuals to further their aspirations and achieve success (or what is 
perceived as success) within their field. The quantity and type of capital that agents are able to control are thereby a reflection of their social position within any given field and as highlighted by Bourdieu and Wacquant (1992, p. 110) "capital does not exist and function except in relationship to a field" and an individual's capital may be substantially different in different fields.

Within the local government environment in NSW, there is a range of different types of capital that may exist. Within local councils there is a hierarchical structure that creates capital due to each individual's position in that social structure. The elected councillors may have the role of guiding the overall policy and direction of the council and therefore the capital in respect of policy, however it is the general manager who is responsible for day to day operations and hence has the capital to influence practice. Individuals such as the finance manager may have capital due to expert knowledge, qualifications and experience which could be used to influence policies and decisions. Other capital may be vested in the educational qualifications, practical experience, capacity to influence policy, or links to community or business of other individuals. Bourdieu (1987, 1990b, 1996) highlighted that individuals within society, in positions of authority, try to hang onto power, not only through controlling physical action but also by dominating the social discourse.

From this it can be seen that by their aggressive marketing techniques, companies such as Iron Securities ${ }^{2}$ challenged the proper order of things at the councils where the interviews took place and (in some cases) alienated the finance managers that they hoped to enrol. However, these finance managers also expressed some concern that these tactics may have been more effective with less experienced finance managers.

One forum within which knowledge and experience is shared in the field of local council finance managers was the "Rock Group" which is an opportunity (by the sponsor) to market to the finance managers but also presents an opportunity for transfer of knowledge, experience and warnings between managers. For example, one council in the Blackwell group had about \$50 million in CDOs before going to one such meeting in 2005 :

Blackwell Council \#6:

[I]t was... at that meeting that I came back and I thought"I am going to have a really good look at what we have got in this portfolio, at what I have inherited", and they [our CDOs]were everywhere. You would have, for example, Ford Motor Company, on 11 [out of 13 of your CDOs]...S o as soon as you had a credit default, Bang, [there would be] credit default on the whole 11 of them. They had these triple CDOs they had all sorts of things and names for them and the names were repeated and it became [clear] when you looked... across thef CDOs that were out there, there were a lot of companies that were duplicated in a lot of these[CDOs].

\footnotetext{
${ }^{2}$ Name changed. Marketers of CDO related products.
} 
They were in the same names and hence I went down from about $\$ 52$ million [Blackwell Council \#6's investment in CDO related products] to about $\$ 19$ million [and] I made sure that the portfolio that we had basically did not double up a lot on these names and that they were reasonable products.

This council then decided to reduce the numbers and amount of their investments in CDOs. Their CDO investment portfolio had been reduced to $\$ 23$ million when the GFC occurred and as a subsequence lost $\$ 5$ million of their original investments, as well as not receiving a returns on their investments within another 10 million of investments for up to four years.

The social / group context was also mentioned by Applewood Council 2:

Local government is a funny place as well, everyone really talks to each other as you will find as you go around. Yeah, so I would be talking to other finance managers "what do you think of this? What do you think of that?".

Another factor that led to these councils not being far more involved with investing council funds in CDOs was their view of the role of council being primarily one of stewardship over the funds rather than seeking maximum return on investment. Participants distrusted the aggressive marketing tactics of CDO sellers, and felt that the proper role of council was primarily to act as a steward of ratepayers' money rather than to maximise return on investment of these funds.

\section{Applewood Council \#3}

'All in all we are very conservative, and this comes right from our councillors down. I have had to report [on this matter]and stress to the councillors that we have not been involved with CDOs... Since the CDO [issue arose] I suppose we have had a new council come in. We had the old council asking, "what was our exposure to CDOs?" We said, "nil". we had the new council asking "what was our exposure to CDOs?" We said "nil". Every now and then ratepayers will write to us, (I have had about half a dozen over the last few years) asking, "what was council's exposure to CDOs?" We keep saying, "nil"... We have to maximise our return but ... no one is going to thank us if we invest in something that falls over... without a doubt, yeah, it is the rate payers' money, it is not our money.

Cedarvale Council \#4 :

No, I think it [our decision to invest only conservatively in CDOs] comes more from the requirements around prudentially managing the portfolio... We look at it as, "this is someone else's money that we are investing". It is there for us to provide infrastructure for [the] community and so that is essentially what drives the capital preservation aspect

From these comments, it can be seen that, although the Local Government Act, (1993) allowed finance managers to invest council funds in a range of sophisticated investment products such as CDOs, some aspects of the habitus, field, and capital (or lack of knowledge capital when a finance 
manager realised they really did not understand CDOs) served to protect local councils from losing more in the GFC than might otherwise have been the case.

The finance manager of Blackwell Council \#6 took over management of financial investments in his council in 2003 when the council had around $\$ 50$ million invested in CDOs. He was annoyed by the aggressive marketing techniques used by marketers associated with promoting CDOs. It was talking to other council finance professionals and an education session in which some of the duplications and risks inherent in CDOs was explained to him, that encouraged him to divest Blackwell's CDOs down to about $\$ 23$ million. This council lost approximately $\$ 5$ million in the GFC but it may have been substantially more if they had continued with the high CDO investment strategy.

The finance officer at Blacwell Council \#4 was considered an experienced officer and there was little oversight of his actions. He was assigned expected performance levels and, while he continued to achieve them, he was left to his own devices. It was his own assessment of the risk of CDOs which determined if these products should be considered. From Bourdieu's perspective, this showed that the capital vested in the individual allowed him unfettered action.

Cedarval Councils \#2 and \#4 had sophisticated software and systems for managing their investment processes and emphasised that they were far more conservative in investments than the 1993 Act would have required them to be. This was because they felt that trading in CDOs was really not the role of council. Cedarvale councils did invest in some CDOs and take some losses but they emphasised that they did this with a good level of technical knowledge (capital) and that their strategy was to hold CDOs to maturity depending on when cash flow was required, rather than trading them:

\section{Cedarvale Council \#3}

Yes... it is not as if we took the things[CDOs] on blindly - which is one of the reasons why we never joined any class actions because we did research and I am not going to stand up in court and say, "we went into this blindly, because someone misled us". We actually went in and did studies and, as I said, the reason why the thing [our Council's investment in CDOs]never expanded into a huge area was that we saw credit risks in them. Effectively they were just creating [the] same risks in different products. When we went into the things we only did them in small parcels of \$2 million normally. So, when they have fallen over like these two [CDOs] have now, we are sitting on a loss of [only] \$5 million dollars.

As regards the fourth set of councils, The Federal Court commented on their (the four councils in the class action against Lehman Brothers and Grange Securities) capital in the matter of sophisticated investment: 
The current case involves three local Australian councils representing a class action that includes non-profit and charity claimants. That in itself is interesting. Given the societal implications, it is curious that litigation of this nature was left to commercial funders, listed on the Australian Stock Exchange for profit, rather than the regulator funded by the taxpayer to uphold the public interest. The Federal Court found that "the improvidence, and commercial naivety, of Grange's council clients in entering into these transactions, that were highly advantageous to Grange, "(at 266) could only have occurred because the investment bank was dealing with officials variously described as "financially quite unsophisticated and completely out of his depth" (at 483), "uninformed" (at 491), and "careless" (at 462)'. (O'Brien, 2012).

\section{Discussion}

It can be seen from these interviews that field and capital are interwoven with habitus. As actors operate and become involved within a particular field, the habitus is shaped, in turn causing actions to be shaped, which then act to reproduce the field. The capital controlled by agents defines their position within the field, the position held allows possibilities for action and hence the capacity to influence and reshape the habitus. Applying this logic to local governments, habitus is constructed by the social context in which it operates (the field), and actions of the actor, depending on their level of capital, are able to shape the nature of the organisation.

Thus, Applewood Councils finance managers realised that they had little knowledge capital in the area of CDOs, felt that CDOs were products that were inconsistent with their role of stewardship over council funds and they were also distrustful of violations of proper hierarchy involved with CDO marketing techniques by those selling the products. Consequently even though the 1993 Local Government Act allowed Applewood Councils to invest in CDOs, the habitus of the council and those charged with making investment decision meant that they chose not to invest in CDOs. The habitus of the council dictated that a good system of managing local government finances ought to include a clarity of accountability (Bailey 2003) and that uninformed, or under informed decisions, did not fit with their perception of proper management. This habitus also aligned with the habitus of the finance managers who used their capital to support the existing habitus of the organisation.

Blackwell Councils werequite heavily invested in CDOs following the $1993 \mathrm{Act}$, and this was largely due to the habitus of the council. The council had previously made some very successful but high risk investments. This success encouraged a habitus that fostered an investment strategy that neglected proper risk assessment. However, through interaction with peers via a particular seminar, AG developed an understanding of the complex structure of CDOs which lead to adjustments to his knowledge capital. This resulted in AG divesting the investment portfolio of more than half of his Blackwell Council's CDOs by the time of the GFC. This decision meant that Blackwell was not as exposed to the collapse of the CDO market as might otherwise have been the case. The capital developed by the finance manager meant that he was able to recognise the risks associated with 
investments in CDOs, and when that risk was recognised, to unilaterally make the decision to sell some of the CDOs and reduce the council's exposure to failure of the product. This demonstrated that even though the habitus of the council encouraged risk to achieve higher returns, the finance manager held sufficient capital to act and reduce the exposure of the council.

Cedarvale Councils had by far the highest capital in terms of investment knowledge about CDOs, they invested in training and provided resources so that the finance staff could develop a good knowledge of different financial instruments. The habitus of the council encouraged investment in a wide range of products but only if they had a good understanding of the associated risks. They accepted that higher returns normally meant associated higher risk and the habitus of the council encouraged acceptance of higher risk provided that the risk was understood. Their view of the proper role of councils being to hold investments to maturity and match investments with cash flow requirements rather than maximising returns through trading in sophisticated products. This approach served to insulate them somewhat from the market collapse, as they held the CDOs to maturity rather than reacting to the market failure and selling out at a loss. They had a good understanding of the product and how it worked so were able to make well informed decisions.

This was not the case with Wingecarribee Shire Council and the other councils who joined with them in the class action against Grange Securities and Lehman Brothers:

Justice Rares (O'Brien, 2012) is disarmingly forthright: "The nature and risks of a CDO are concepts that are beyond the grasp of most people ... Nonetheless, Grange portrayed itself as an expert in these investments. Most certainly, none of the seven council officers who gave evidence had any expertise in these financial products. Grange knew and preyed on that lack of expertise and the trust the councils placed in its expert advice" (at 410).In a remarkably detailed judgement, the Federal Court holds that Grange could only do so by actively circumventing the stated objection of its clients. The point is highlighted in dealings with Wingecarribee Council. "Grange tested the water" and when the official "bit" he was "reeled in" by "words of comfort" (at 662). The councils believed that "they had the best of both worlds: principal protection and increased interest. For Grange, this manner of allaying risk averse, financially unsophisticated council officers' fears of CDOs, was as easy as shooting fish in a barrel" (at 662).

(Justice Rares quoted in O'Brien 2012).

\section{Conclusion}

The investment policy governing financial investments by NSW councils has substantially changed over the last two decades. This could be argued to be part of a general policy shift towards neoliberal narratives (Bevir 2011). From a very conservative and restrictive approach prior to 1993 the policy has gradually been relaxed allowing more aggressive financial investments. By 2000 
investment in financial instruments was allowed (provided the councils understood the risk). This meant that there were some restrictions on the types of investments but that it did not restrict the level of risk that could be taken. The only requirement was that the councils should understand the risk. This meant that although councils and financial investment managers established their own acceptable levels of risk, the level of risk a public sector entity should take is open to interpretation. While taking risks for higher returns may be acceptable and even viewed as desirable in the private sector, this may not be viewed the same way in the public domain (Hood, Stein \& Jarman2013).

Since the GFC and collapse of the markets for CDOs and other financial instruments, the policy has changed again. The policies are now very restrictive and councils are unable to invest in any products that are unsecured. This means that almost all investments are now in term deposits with the major banks. The public sector organisations are now being judged on their decisions and forcibly restrained from taking on products with any level of risk (Kelly 2011).

Investment decisions within NSW councils are governed by the investment guidelines issued by Treasury. Up until the GFC the restrictions on financial investments gradually became less regulated and it was up to the individual councils to determine the level of risk that they were willing to accept when making financial investments. It could be argued that the changes to the Ministerial restrictions placed on financial investments may have encouraged NSW local councils to take on investments with higher risk than they would normally consider. Councils with unsophisticated and inexperienced finance managers may have assumed that reliance on, and compliance with, the investment policy was a mechanism for adequate governance and that the Ministerial guidelines provided an underlying determination of acceptable risk (which in the case of CDOs meant accepting high risk investments). In making the decision to invest (or not) in CDOs, it can be seen that the relaxation of the NSW ministerial guidelines may have led individual local councils toward higher risk products, when in reality the onus was being placed on the respective council to determine which products they were willing to invest in and the risks that they were willing to accept. Individual councils had the ability to manage the level of risk that they were willing to undertake and to control the actions of the financial managers through their own investment policies.

Bourdieu's Theory of Practice has provided a framework to analyse the actions of financial investment officers within councils. The regulatory field of Ministerial guidelines provided a control over behaviour however, when constraints within this field were relaxed, investment managers desiring a more aggressive and risk accepting approach were able to indulge in those practices. Investment policies within councils created an additional boundary that was able to control behaviour. An example of a less confining field that was still able to exert influence was the finance 
managers' group. This field allowed group analysis of issues providing different perspectives and was able to exert a level of professional scepticism over investment decisions by individuals.

Aggressive marketing techniques concerned some finance managers and diminished their perceptions of the products. Experienced finance managers felt that the way the products were marketed violated the way decisions should be made and that less experienced finance managers may be improperly influenced. Prior experiences serve to build the instructional knowledge and hence the habitus hopefully leading to better decisions. However, prior success with high risk investments also served to influence the habitus, with some councils who had been successful with high investments actively pursuing high risk and high return products.

Bourdieu's explanation of capital was used to show that where there was capital invested within an individual it was able to be used to shape action. Finance managers with capital were able to take action within other constraints. Levels of trust and perceived knowledge meant that some individuals were able to make decisions without any significant levels of oversight. Provided they were meeting the expected levels of performance their actions were not reviewed.

Financial investment decisions made by local councils take place within a social context. Hierarchies exist within councils, the investment policy of each council was able to control the actions of investment managers and restrict the level of risk to a level evaluated as acceptable. Finance managers of councils were provided with a policy that determined the level of risk that the council was willing to accept and then provided with the autonomy to make decisions within those guidelines. Finance managers with high risk acceptance were constrained by the council policy, while those with low risk acceptance were able to lower the risk taken even further below what the council would accept. The finance managers group provided mechanisms, training and peer advice which affected the habitus and willingness to accept risk of the group. However, ultimately it was the habitus and acceptance of risk within each of the individual local councils, which was the crucial component in the determination of whether or not they were disposed to engage in these types of investments. The investment guidelines from the state government set one benchmark, but it was up to each council to determine what they were willing to accept and set an appropriate benchmark for themselves. This was determined by the councils and the individuals entrusted with making these decisions which meant that the policy adopted was fabricated from the habitus of the council and influenced by the habitus and relative capital of the finance managers.

This paper has shown that local councils need to consider how they manage and control behaviour. If excessive capital is left in the hands of individuals then the organisation may loss control. Policies 
of external bodies such as the state government have the ability to set constraints yet, it is the policy, controls and actions of the council that determines the ultimate behaviour of its members. If the council has established controls and expectations linked to policies reflecting the organisations goals then council officers will abide by them even if contrary to the individuals own inclinations. 


\section{REFERENCES}

Adam, M, Jhooty, M \& Wong, J 2004, CDO Methodology. Dominion Bank report accessed 17/04/2012.

http://www.dbrs.com/search/documentList/sort/false/type/quick/page/1?query=CDO Methodology

Bailey, S. J., 2003. More tinkering with local government finance, Local Government Studies, 29:1, 17-32, DOI:10.1080/714004175

Benmelech, E \& Dlugosz, J 2009, The alchemy of CDO credit ratings, National Bureau of Economic Research, Cambridge, pp1-42.

Berard, T. J., 2005. Rethinking practices and structures. Philosophy of the Social Sciences 35: 196-230.

Bevir, M., 2011. Democratic Governance: A Genealogy, Local Government Studies, 37:1, 3-17, DOI: 10.1080/03003930.2011.539860Black, S \& Rai, A 2005, Collateralised debt obligations in Australia, Financial Stability Review, accessed 26/08/2012, http://www.rba.gov.au/publications/bulletin/2007/nov/pdf/bu-1107-1.pdf.

Bourdieu, P., 1977. Outline of a theory of practice, Cambridge University Press.

Bourdieu, P., 1984. Distinction: A social critique of the judgement of taste. London, Routledge.

Bourdieu, P., 1987. What makes a social class? On the theoretical and practical existance of groups. Berkley Journal of Sociology: A Critical Review 32: 1-17.

Bourdieu, P., 1990. The logic of practice. Cambridge, Polity Press.

Bourdieu, P., 1996. "Understanding." Theory, Culture Society 13(2): 17-37.

Bourdieu, P. and L. J. D. Wacquant, 1992. An invitation to reflexive sociology. Chicago and London, University of Chicago Press.

Breiger, R. L., 2000. A tool kit for practice theory. Poetics 27: 91-115.

Carnegie, G D 2005, Promoting accountability in municipalities, Australian Journal of Public Administration, vol.643, pp78-87.Cole, M., 2008. Review of NSW Local Government investments - Final Report, Sydney, ACAY Consulting. 
DLG 2006, Investment Requirements for NSW Councils. Department of Local Government. NSW. accessed 03/08/2011 http://www.dlg.nsw.gov.au/dlg/dlghome/documents/Circulars/0670.pdf

Dollery, B, Fletcher, M \& Rao, DSP 1998, Funding local government in Australia: The evolution of untied commonwealth financial assistance, Journal of Public Budgeting, Accounting \& Financial Management, vol.104, pp481-498.

Dollery, B, Wallis, J \& Allan, P 2006, The debate that had to happen but never did: the changing role of Australian local government, Australian Journal of Political Science, vol.414, pp553-567.

Dredge, D 2001, Local government tourism planning \& policy-making in New South Wales: Institutional development and historical legacies Current Issues in Tourism vol.42, no.4, pp355-380.

Eslake, S 2011a, The Australian economy, Economics Society of Australia Victorian Branch Outlook, Melbourne.

Eslake, S 2011b, Economic Outlook for Australia, CEDA's Annual Economic and Political Overview, Hobart.

Emirbayer, M. and V. Johnston, 2008. Bourdieu and organisational analysis. Theory Culture Society 37: 1-44.

Hood, J., Stein, B, and M. Jarman, 2013. Public sector risk financing: Exploring the potential use of weather derivatives by fire and rescue services. Local Government Studies. 39:4, 562-581, DOI:10.1080/03003930.2012.751021

Hurtado, P. S., 2010. Assessing the use of Bourdieu's key concepts in the strategy-as-practice. Competitiveness Review: An International Business Review 20(1): 52-61.

Jones, G \& Bowrey, G, 2010, Local government investment: A form of gambling, Australasian Journal of Regional Studies, vol.161, pp37-50.

Kelly, J., 2011. From recession to renewal: The impact of the financial crisis on public services and local government. Local Government Studies. 37:6, 689-690,

DOI:10.1080/03003930.2011.632569 
Levin, C \& Coburn, T 2011, Wall Street and the financial crisis: Anatomy of a financial collapse. Committee on Homeland Security and Governmental Affairs, U.S. Senate Permanent Subcommittee on Investigations.

Local Government Act 1993. New South Wales Consolidated Acts.

Local government Act 1993-Invesment Order, 2011 accessed 22/07/2011

http://www.olg.nsw.gov.au/sites/default/files/Investment-Order-12-1-2011.pdf

NSW Department of Local Government (DLG), (2000), NSW Department of Local Government Circular to Councils: Forms of investment-Minister's order and investment guidelines, Circular No. 00-16

NSW Department of Local Government (DLG), (2008), NSW Department of Local Government Circular to Councils: Council invested funds and the Cole inquiry report, Circular No. 08-10

NSW Trustees Act 1925. No 14. New South WalesWacquant, L. (2004). Pointers on Pierre Bourdieu and democratic politics. Constellations 11(1): 3-15.

O'Brien, J. 2012 Understanding the Federal Court's Landmark Ruling Against Lehman Brothers. The Conversation, Spetember 24, 2012 available at http://theconversation.com/understandingthe-federal-courts-landmark-ruling-against-lehman-brothers-9759

Partnoy, F \& Skeel, DAJ, 2006, The promise and perils of credit derivatives, Scholarship at Penn Law Paper 125.

Ray, R 2006, CDOs cubed: The first-ever triple derivative, Derivatives Use, Trading \& Regulation, vol.123, pp183-189.

RBA 2012, The Australian Economy and Financial Markets: Chart Pack, accessed 02/09/2012, http://www.rba.gov.au/chart-pack/interest-rates.html.

Rolfe, J 2009, NSW council millions melt like ice in Iceland, Daily Telegraph, 29 May, accessed 07/09/2012, http://www.dailytelegraph.com.au/news/nsw-council-millions-melt-like-ice-iniceland/story-e6freuy9-1225717628068

Tett, G 2007, 'Risky' CDOs remain alluring', Financial Times, 5 July, accessed 28/02/2012 http://www.ft.com/cms/s/1/5232ca08-2b0e-11dc-85f9-000b5df10621.html

Tett, G 2009a, Icebergs and ideologies: How information flows fuelled the financial crisis, Anthropology News, pp6-7. 
Tett, G 2009b, Lost through destructive creation, Financial Times, 9 March, accessed 27/08/2012 http://www.ft.com/intl/cms/s/0/0d55351a-0ce4-11de-a5550000779fd2ac.html\#axzz2ObtGFKU5

Tett, G 2010, 'Fool's Gold: The Inside Story of J.P. Morgan and How Wall St. Greed Corrupted Its Bold Dream and Created a Financial Catastrophe', Free Press.

Webb, J., T. Schirato and G. Danaher, 2002. Understanding Bourdieu. Crows Nest NSW, Allen and Unwin.

William Roberts Lawyers 2015 'Wingecarribee Shire Council v Lehman Brothers Australia: banking and finance - misselling of complex fincial product.' Available http://www.williamroberts.com.au/News-and-Resources/News/Case-Studies/Wingecarribee-ShireCouncil-v-Lehman-Brothers-Australia-Ltd--banking-and-finance---misselling-of-complex-financialproduct accessed 12 December, 2015. 